\title{
Perbandingan Strategi Pengajaran Flipped Classroom dan Konvensional pada Mata Kuliah Teoritis dan Hitungan Saat Pembelajaran Jarak Jauh
}

\author{
Viola Kristianada ${ }^{1}$, Winda Halim ${ }^{2 *}$ \\ 1,2Program Studi Teknik Industri, Universitas Kristen Maranatha, Bandung, Indonesia \\ (*winda.halim@eng.maranatha.edu)
}

\begin{abstract}
Abstrak - Pandemi Covid-19 yang saat ini masih berlangsung di seluruh dunia memaksakan perubahan berbagai kebiasaan sehari-hari dalam hidup. Salah satunya terkait dengan proses belajar mengajar yang saat ini dilakukan secara jarak jauh. Proses belajar mengajar yang dilakukan secara daring ini memaksa baik dosen maupun mahasiswa untuk beradaptasi dengan baik karena suasana belajar yang tentunya sangat berbeda dengan saat hadir langsung di dalam kelas. Metode pengajaran yang dilakukan dosen saat ini pun sangat beragam yaitu ada yang menggunakan metode konvensional, yaitu ceramah dengan menggunakan platform video conference, serta terdapat pula yang menggunakan metode flipped classroom. Penelitian ini bertujuan untuk membandingkan kedua metode tersebut untuk mata kuliah yang bersifat teoritis (tidak ada responsi) dan hitungan (ada responsi). Berdasarkan pengolahan data yang dilakukan maka diperoleh hasil bahwa tidak ada perbedaan yang signifikan baik untuk metode RSME dan NASA TLX, untuk strategi pengajaran konvensional atau flipped classroom untuk mata kuliah yang bersifat teoritis atau hitungan. Sehingga dapat disimpulkan bahwa proses pembelajaran jarak jauh ini memberikan beban mental yang cukup besar walaupun disajikan menggunakan strategi pengajaran apapun juga. Untuk meringankan beban mental mahasiswa dapat digunakan cara seperti membuat suasana kelas lebih kondusif dengan komunikasi dua arah, materi disajikan dengan lebih menarik, dan memberikan pendampingan saat proses pembelajaran dilakukan.
\end{abstract}

Kata kunci: daring; flipped classroom; hitungan; konvensional; teoritis

\section{PENDAHULUAN}

Pandemi Covid-19 yang telah berlangsung lebih dari 1 tahun dan menjangkiti hampir seluruh dunia, telah merubah berbagai kebiasaan manusia dalam melaksanakan kegiatannya sehari hari, misalnya saja pekerja kantor yang bekerja dari rumah atau sering disebut dengan istilah WFH (Work From Home), serta para pelajar dan mahasiswa yang harus melaksanakan kegiatan belajar mengajar secara daring atau sering disebut sebagai Pembelajaran Jarak Jauh (PJJ). Pembelajaran Jarak Jauh (PJJ) menggunakan teknologi seperti komputer, laptop, atau gawai yang telah tersambung dengan jaringan internet untuk dapat mengakses materi dan mengikuti kegiatan pembelajaran lainnya. Proses belajar ini tentu berbeda dengan aktivitas belajar yang dilakukan secara langsung di kelas. Penelitian dilakukan untuk mengetahui tingkat stress yang dialami oleh seorang siswa (Harahap, Harahap, \& Harahap, 2020) dimana tingkat stress yang diperoleh berada pada kategori sedang. Kemudian terdapat penelitian lain yang menganalisis kebijakan PJJ ini yang ternyata masih memiliki berbagai kendala seperti peralatan, koneksi internet, dan hasil pembelajaran dirasakan kurang efektif (Sari, Rifki, \& Karmila, 2020).

Berbagai strategi pembelajaran dilakukan salah satunya adalah menggunakan flipped classroom. Flipped classroom merupakan kegiatan pembelajaran yang dilakukan dengan membagikan materi pembelajaran sebelum kelas dimulai. Flipped classroom ini juga sebagian besar dilakukan secara online dan merupakan jenis pendekatan pembelajaran campuran (blended learning) (Susanti \& Hamama Pitra, 2019) dan merupakan model pembelajaran yang dilakukan dengan cara meminimalkan frekuensi instruksi yang dilakukan secara langsung dan memaksimalkan interaksi satu per satu (Johnson \& Johnson, 2013). Tetapi, selain metode tersebut masih banyak juga dosen yang memakai cara konvensional yaitu dengan memberikan ceramah secara langsung kepada mahasiswa pada jam perkuliahan tersebut berlangsung dengan menggunakan platform video conference yang ada misalnya Zoom.

Kedua strategi pembelajaran ini tentunya memiliki dampak bagi para mahasiswa, baik berdampak secara langsung maupun tidak langsung. Berdasarkan kuesioner pendahuluan yang disebarkan mahasiswa memiliki beban mental yang berbeda jika mereka sedang mengikuti mata kuliah yang mereka sukai atau mata kuliah yang tidak mereka sukai. Pada mata kuliah yang kurang disukai atau tidak favorit sebanyak $75 \%$ merasa bahwa mereka terbeban secara mental, sedangkan untuk mata kuliah favorit walaupun lebih rendah yaitu $48 \%$, mereka tetap merasa terbeban secara mental. 


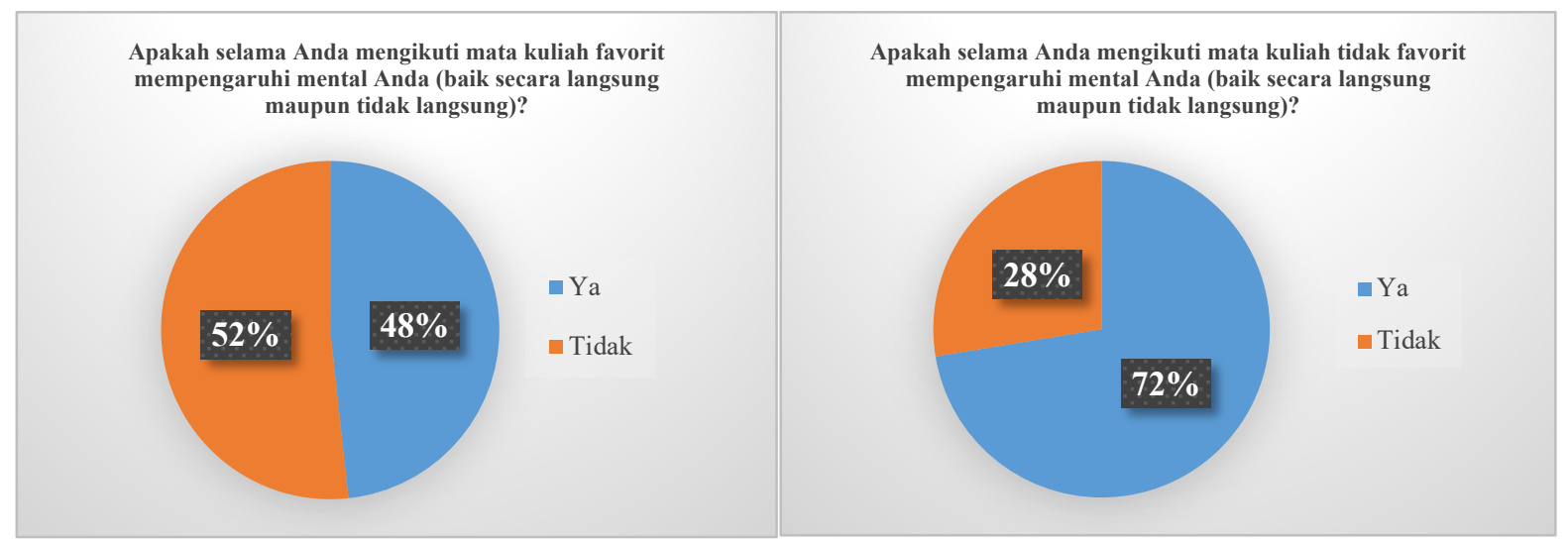

Gambar 1. Hasil Kuesioner Pendahuluan

Pada penelitian ini ingin diketahui perbandingan antara strategi pembelajaran flipped classroom dan konvensional yang diterapkan pada mata kuliah yang bersifat teoritis, atau mata kuliah yang tidak terlalu banyak rumus dan perhitungan sehingga tidak ada responsi, dan mata kuliah yang bersifat hitungan, atau mata kuliah yang memiliki banyak angka, rumus, dan membutuhkan kegiatan responsi tambahan. Mahasiswa dipandang belum memahami materi dalam strategi pembelajaran konvensional. Maka dari itu, mahasiswa hanya menerima materi pembelajaran yang diberikan oleh dosen (Sahimin, Nasution, \& Sahputra, 2017). Parameter yang akan digunakan adalah beban mental dari mahasiswa yang diukur menggunakan 2 metode yaitu RSME (Rating Scale Mental Effort) dan NASA-TLX (National Aeronautics \& Space Administration Task Load Index). Kedua metode tersebut digunakan karena keduanya adalah metode yang cukup mudah digunakan untuk mengukur beban mental, misalnya RSME hanya memiliki satu dimensi saja, sedangkan NASA TLX digunakan karena memiliki sensitivitas yang lebih tinggi dibandingkan dengan SWAT (Prayogo, 2016).

\section{STUDI LITERATUR}

\section{A. Strategi Pembelajaran Flipped Classroom}

Model pembelajaran Flipped Classroom merupakan jenis pembelajaran pendekatan campuran (blended learning) dan sebagian besar dilakukan secara online (Susanti \& Hamama Pitra, 2019), dimana model flipped classroom siswa dapat belajar dari video tutorial yang diberikan oleh guru. Sehingga pada saat siswa belajar menjadi tidak mudah bosan karena hanya mendengarkan penjelasan dari seorang guru. Pada pembelajaran dengan flipped classroom siswa dapat mempelajari topik secara individu, yang biasanya dibantu dengan menggunakan pelajaran video yang dibuat oleh instruktur. Kemudian pada saat di dalam kelas, siswa mencoba menerapkan pengetahuan yang didapat dengan cara memecahkan masalah dan melakukan praktek, dan karena siswa dapat mengakses video dimanapun, maka siswa dapat belajar dimana saja dan diulang-ulang, akibatnya ketika proses pembelajaran diulang-ulang, maka dapat mempengaruhi hasil belajar yang didapat.

\section{B. Strategi Pembelajaran Konvensional}

Strategi pembelajaran konvensional yang umum dilakukan di kelas selama ini, yaitu pembelajaran yang memandang siswa berkemampuan tidak berbeda sehingga mereka mendapat pelajaran secara bersama, dengan cara yang sama dalam satu kelas sekaligus. Model yang digunakan pada pembelajaran klasikal adalah model pembelajaran langsung (direct learning), dimana dalam model pembelajaran ini memberikan kesempatan untuk semua siswa berpartisipasi dalam kelas, baik secara aktif terlibat dalam pembelajaran, atau pasif tidak terlibat, atau hanya mendengar dan mencatat apa yang didapat dalam kelas.

\section{Rating Scale Mental Effort (RSME)}

Rating Scale Mental Effort (RSME) merupakan metode yang digunakan untuk menganalisis beban kerja mental yang dihadapi oleh pekerja yang harus melakukan berbagai aktivitas dalam pekerjaannya, dimana 
merupakan metode yang menggunakan skala rating/skor dari pekerjaan mental. Dan Rating Scale Mental Effort (RSME) merupakan pengukuran beban kerja mental subyektif dengan skala tunggal yang dikembangkan oleh Zijlstra (Ziljstra \& Van Doom, 1985; Zijltra, 1993) dalam (Widyanti, Jonhson, \& de Waard, 2013). Rating Scale Mental Effort (RSME) merupakan sebuah instrumen uni-dimensi yang digunakan untuk mengukur beban kerja mental subjektif. Rating Scale Mental Effort (RSME) terdiri dari garis yang memiliki panjang $150 \mathrm{~mm}$ yang ditandai dengan sembilan titik jangkar, masing-masing disertai dengan lebar deskriptif yang menunjukkan tingkat upaya. Alat ukur ini mudah untuk digunakan, karena hanya memerlukan biaya yang relatif cukup murah dan merupakan alat ukur yang valid (Pandiangan, Mahachandra, \& Handayani, 2019; (Widyanti, Jonhson, \& de Waard, 2013).

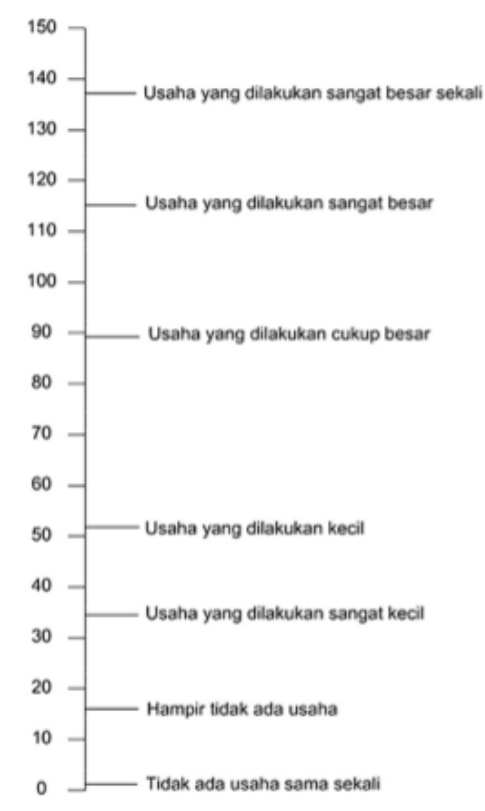

Gambar 2. Keterangan Skala Usaha RSME

D. NASA-TLX (Febriani, Febiyani, \& Ma'sum, 2021)

NASA-TLX (National Aeronautics \& Space Administration Task Load Index) merupakan sebuah prosedur peringkat multi-dimensi yang menyediakan skor beban kerja keseluruhan berdasarkan rata-rata tertimbang pada keenam dimensi (Human Performance Research Group, 1986). Dan NASA-TLX dapat dikatakan sebagai sebuah alat untuk mengukur dan melakukan penilaian beban kerja mental subjektif (MWL). Ini memungkinkan Anda untuk menentukan MWL peserta saat mereka melakukan tugas. Ini menilai kinerja di enam dimensi untuk menentukan peringkat beban kerja secara keseluruhan, dimana dimensi keenam penilaian tersebut meliputi:

1. Mental Demand: berkaitan dengan aktivitas mental dan persepsi yang dibutuhkan untuk berpikir, mengambil keputusan, menghitung, mengingat, dan mencari.

2. Physical Demand: berkaitan dengan aktivitas fisik yang dibutuhkan untuk melakukan pekerjaan.

3. Temporal Demand: berkaitan dengan tuntutan waktu selama mengerjakan pekerjaan.

4. Performance: berkaitan dengan kinerja mahasiswa untuk mencapai target kuliah.

5. Effort: berkaitan dengan tingkat usaha baik secara fisik maupun psikis yang dilakukan untuk menyelesaikan pekerjaan.

6. Frustation Level: berkaitan dengan rasa stress, tidak nyaman, dan terusik selama mengerjakan tugas. 
Tabel 1

Kategori Beban Kerja Mental NASA-TLX

\begin{tabular}{c|c|}
\hline Kategori Beban Kerja Mental & Nilai Rata-Rata WWL \\
\hline Rendah & $0-9$ \\
\hline Sedang & $10-29$ \\
\hline Agak Tinggi & $30-49$ \\
\hline Tinggi & $50-79$ \\
\hline Sangat Tinggi & $80-100$ \\
\hline
\end{tabular}

Sumber: (Rachmuddin, Dewi, \& Dewi, 2021); (Hartt \& Staveland, 1988)

Tabel 2

Keterangan Skala dan Rating

\begin{tabular}{|c|c|c|}
\hline Skala & Rating & Keterangan \\
\hline $\begin{array}{c}\text { Kebutuhan } \\
\text { Mental }\end{array}$ & Rendah/Tinggi & $\begin{array}{c}\text { Kegiatan mental yang diperlukan } \\
\text { untuk melakukan aktivitas seperti } \\
\text { menganalisis, dll. }\end{array}$ \\
\hline $\begin{array}{c}\text { Kebutuhan } \\
\text { Fisik }\end{array}$ & Rendah/Tinggi & $\begin{array}{c}\text { Aktivitas fisik yang dilakukan ketika } \\
\text { melaksanakan aktivitas perkuliahan } \\
\text { (menulis, mengetik, dll). }\end{array}$ \\
\hline $\begin{array}{c}\text { Kebutuhan } \\
\text { Waktu }\end{array}$ & Rendah/Tinggi & $\begin{array}{c}\text { Tekanan waktu yang dirasakan } \\
\text { selama mengerjakan tugas atau } \\
\text { praktikum yang santai maupun yang } \\
\text { melelahkan secara garis besar. }\end{array}$ \\
\hline Performansi & Rendah/Tinggi & $\begin{array}{c}\text { Berkaitan dengan keberhasilan dan } \\
\text { kepuasan mahasiswa terhadap hasil } \\
\text { kerjanya. }\end{array}$ \\
\hline Usaha & Rendah/Tinggi & $\begin{array}{l}\text { Terkait dengan gabungan antara } \\
\text { usaha mental dan kegiatan fisik yang } \\
\text { diperlukan untuk menuntaskan } \\
\text { pekerjaan (baik tugas harian } \\
\text { maupun tugas dari lab/praktikum) }\end{array}$ \\
\hline Level Frustasi & Rendah/Tinggi & $\begin{array}{c}\text { Berkaitan rasa tidak nyaman dan } \\
\text { putus asa dibandingkan dengan rasa } \\
\text { aman, nyaman, dan puas secara } \\
\text { keseluruhan. }\end{array}$ \\
\hline
\end{tabular}

Sumber: (Febriani et al., 2021)

\section{METODOLOGI}

Langkah-langkah yang dilakukan pada penelitian ini adalah menentukan populasi yang akan diteliti, pada penelitian ini responden berasal dari salah satu program studi di Universitas X. Selain itu dilakukan beberapa pembatasan kriteria responden mahasiswa yang dapat mengisi kuesioner yang dibagikan yaitu terkait dengan angkatan dan IPK responden. Mahasiswa yang akan dijadikan responden adalah mahasiswa dari angkatan 2017-2019 yang memiliki IPK minimal 2,7. Hal ini dilakukan untuk menjamin data yang diperoleh memiliki kualitas yang baik, karena diisi oleh angkatan yang sedang aktif dan oleh responden dengan nilai IPK yang cukup baik. Setelah itu dilakukan penyusunan kuesioner yang berisi beberapa pertanyaan awal untuk melakukan pemetaan terhadap responden dan dilanjutkan dengan kuesioner RSME dan NASA-TLX. Kuesioner dibagikan secara online menggunakan media google form, sehingga data yang diterima kemudian akan diperiksa dan difilter kembali oleh peneliti, hasilnya kemudian dilakukan pengujian validitas dan realibitas.

Data yang terkumpul kemudian dirangkum dan diolah menggunakan metode Uji $\mathrm{t}$ berpasangan. Pengujian $t$ berpasangan ini dilakukan karena responden yang mengisi kuesioner RSME dan NASA TLX 
baik untuk strategi pembelajaran konvensional dan flipped classroom untuk masing-masing jenis mata kuliah adalah mahasiswa yang sama, agar hasil antar kedua strategi pembelajaran tersebut dapat dibandingkan. Sehingga, dapat diperoleh hasil untuk kemudian dilakukan analisis dan usulan lebih lanjut.

\section{HASIL DAN DISKUSI}

Pada proses pengumpulan data yang dilakukan terdapat beberapa kendala yang terjadi, antara lain penerapan strategi pembelajaran yang belum merata untuk semua angkatan, tidak semua mahasiswa sedang mangontrak mata kuliah yang bersifat hitungan, terdapat beberapa mata kuliah yang sulit dibedakan apakah menerapkan strategi pengajaran secara flipped atau konvensional karena bervariasi untuk setiap pertemuannya. serta terdapat angkatan yang sudah berada di tingkat akhir, mata kuliah yang diambilnya tidak ada yang menerapkan metode flipped classroom.

\section{A. Perbandingan Antara Strategi Pembelajaran Flipped Classroom dan Konvensional untuk Mata Kuliah Teoritis}

Pada tabel 3 ditampilkan hasil pengumpulan data dari 18 responden yang mengikuti mata kuliah yang bersifat teoritis baik dengan metode konvensional dan metode flipped classroom. Jumlah responden diperoleh dari hasil filterisasi oleh peneliti dengan mempertimbangkan berbagai persyaratan yang ada, yaitu angkatan, IPK, dan mengisi kuesioner secara lengkap. Nilai RSME diperoleh dari hasil penilaian langsung mata kuliah yang dimaksud oleh responden, sedangkan nilai WWL NASA TLX diperoleh dengan melakukan pengolahan nilai indikator seperti kebutuhan mental, kebutuhan fisik, kebutuhan waktu, performansi, usaha, dan level frustasi dari setiap responden.

Tabel 3

Hasil RSME dan WWL NASA-TLX (Sifat Mata Kuliah Teoritis)

\begin{tabular}{|c|c|c|c|c|}
\hline Responden & RSME Konvensional & RSME Flipped & WWL NASA Konvensional & WWL NASA Flipped \\
\hline 1 & 90 & 110 & 78,00 & 70,67 \\
\hline 2 & 85 & 90 & 21,33 & 21,33 \\
\hline 3 & 55 & 90 & 46,67 & 79,33 \\
\hline 4 & 100 & 100 & 83,33 & 86,67 \\
\hline 5 & 55 & 99 & 60,67 & 70 \\
\hline 6 & 140 & 125 & 76,67 & 66 \\
\hline 7 & 100 & 100 & 30,00 & 20 \\
\hline 8 & 100 & 60 & 76,67 & 70 \\
\hline 9 & 50 & 45 & 61,33 & 55,33 \\
\hline 10 & 120 & 100 & 87,33 & 74 \\
\hline 11 & 100 & 90 & 82,67 & 72 \\
\hline 12 & 90 & 80 & 55,33 & 48 \\
\hline 13 & 100 & 100 & 77,33 & 82 \\
\hline 14 & 100 & 140 & 80,00 & 71,33 \\
\hline 15 & 90 & 90 & 70,67 & 94 \\
\hline 16 & 60 & 90 & 67,33 & 712,67 \\
\hline 17 & 70 & 70 & 80,67 & 76,67 \\
\hline 18 & 110 & 90 & & \\
\hline
\end{tabular}


Tabel 4

Hasil Pengolahan RSME dan NASA TLX Jenis Mata Kuliah Teoritis

\begin{tabular}{|c|c|c|c|c|}
\hline Keterangan & T hitung & T tabel & Keputusan & Kesimpulan \\
\hline t hitung Metode RSME & $-0,560251661$ & \multirow{2}{*}{ $\pm 2,109815578$} & Terima Ho & Tidak ada perbedaan signifikan \\
\cline { 1 - 2 } \cline { 5 - 5 } t hitung Metode NASA TLX & $-0,364982497$ & & Terima Ho & Tidak ada perbedaan signifikan \\
\hline
\end{tabular}

Berdasarkan hasil pengolahan data di tabel 4 maka dapat disimpulkan bahwa nilai t hitung untuk kedua metode baik RSME dan NASA TLX memberikan nilai yang lebih kecil dari nilai tabel. Sehingga, keputusan yang diperoleh adalah terima Ho atau bahwa tidak ada perbedaan beban mental yang dirasakan oleh responden untuk mata kuliah yang bersifat teoritis, baik untuk strategi pembelajaran konvensional maupun flipped classroom. Jika melihat hasil pengumpulan data pada tabel 3 memang dapat terlihat bahwa nilai RSME untuk sebagian besar responden adalah lebih dari 90 yang mengindikasikan bahwa usaha yang dikeluarkan cukup besar, beberapa responden ada yang memberikan nilai 55, 60, dan 70 tetapi jumlahnya masih lebih banyak yang memberikan nilai di atas 90. Pada metode NASA TLX nilai WWL yang dihasilkan juga masih berada dikisaran kategori tinggi dan sangat tinggi yaitu lebih dari 50, walaupun ada yang menilai dengan kategori sedang yaitu 20 dan 30 tapi jumlahnya juga tidak terlalu signifikan. Sehingga, dapat disimpulkan hasil yang diperoleh kedua metode adalah sama yaitu kedua strategi pembelajaran memberikan beban mental yang cukup tinggi bagi mahasiswa.

\section{B. Perbandingan Antara Strategi Pembelajaran Flipped Classroom dan Konvensional untuk Mata Kuliah Hitungan}

Pada tabel 5 ditampilkan hasil pengumpulan data untuk 9 orang responden dengan mata kuliah yang bersifat hitungan. Jumlah responden untuk jenis mata kuliah ini masih sedikit karena strategi flipped classroom untuk mata kuliah yang bersifat hitungan masih belum banyak diterapkan oleh dosen pengajar. Sehingga jumlah responden yang menilai bersamaan untuk strategi konvensional dan flipped untuk mata kuliah hitungan hanya sedikit.

Tabel 5

Hasil RSME dan WWL NASA-TLX (Sifat Mata Kuliah Hitungan)

\begin{tabular}{|c|c|c|c|c|}
\hline No & RSME Konvensional & RSME Flipped & WWL NASA Konvensional & WWL NASA Flipped \\
\hline 1 & 100 & 90 & 80 & 76 \\
\hline 2 & 80,00 & 80 & 68,67 & 72 \\
\hline 3 & 70,00 & 70 & 69,33 & 82,67 \\
\hline 4 & 120 & 120 & 79,33 & 76,67 \\
\hline 5 & 80 & 80 & 71,33 & 75,33 \\
\hline 6 & 115 & 115 & 84 & 82,67 \\
\hline 7 & 109 & 109 & 76,67 & 84 \\
\hline 8 & 80 & 80 & 78,67 & 81,33 \\
\hline 9 & 89 & 89 & 77 & 73,33 \\
\hline
\end{tabular}

Tabel 6

Hasil Pengolahan RSME dan NASA TLX Jenis Mata Kuliah Teoritis

\begin{tabular}{|c|c|c|c|c|}
\hline Keterangan & T hitung & T tabel & Keputusan & Kesimpulan \\
\hline t hitung Metode RSME & 1 & \multirow{2}{*}{ $\pm 2,306004135$} & Terima Ho & Tidak ada perbedaan signifikan \\
\cline { 1 - 2 } \cline { 5 - 5 } t hitung Metode NASA TLX & $-1,10249182$ & & Terima Ho & Tidak ada perbedaan signifikan \\
\hline
\end{tabular}

Pada jenis mata kuliah yang bersifat hitungan ini hasil yang diperoleh untuk metode RSME dan NASA TLX juga masih memberikan hasil $t$ hitung yang lebih kecil dari $t$ tabel yang mengindikasikan bahwa keputusan yang diperoleh adalah terima Ho yang berarti tidak ada perbedaan untuk strategi pembelajaran baik secara konvensional atau secara flipped classroom untuk mata kuliah yang bersifat hitungan. Pada nilai yang terlihat dari tabel 5 nilai RSME dan perhitungan WWL untuk NASA TLX masih berada di usaha yang dikeluarkan besar dan kategori tinggi bahkan sangat tinggi. Berdasarkan hasil yang diperoleh terlihat bahwa 
kedua metode memberikan hasil yang sama yaitu strategi pembelajaran yang digunakan baik secara konvensional maupun flipped classroom memberikan beban mental yang cukup tinggi bagi mahasiswa.

Hasil ini tentunya harus mempertimbangkan bahwa penelitian ini memiliki berbagai keterbatasan yaitu ruang lingkup penelitian hanya berpusat pada salah satu program studi pada salah satu universitas sehingga jumlah responden juga terbatas. Jika dilakukan penambahan responden dan memperluas ruang lingkup penelitian tidak menutup kemungkinan bahwa dapat diperoleh hasil yang berbeda.

Proses pembelajaran jarak jauh yang dilakukan secara mendadak dan terpaksa yang disebabkan oleh pandemi Covid 19 ini memberikan dampak yang cukup besar bagi perkembangan proses belajar seorang mahasiswa, walaupun jika dilihat dari usia mereka berada pada tahap perkembangan konkret (Santrock, 2008) yang dapat melakukan pengambilan keputusan sendiri. Faktor durasi waktu belajar yang lama, kejenuhan, suasana belajar di rumah, proses komunikasi yang kadang terhambat dapat menjadi penyebabpenyebab lain yang juga dapat diteliti lebih lanjut.

\section{KESIMPULAN}

Berdasarkan hasil yang diperoleh untuk kedua metode pengukuran beban mental yaitu RSME dan NASA TLX dan kedua strategi pembelajaran untuk sifat mata kuliah teoritis dan hitungan, semuanya memberikan hasil yang tidak ada perbedaan yang signifikan. Maka dapat ditarik kesimpulan bahwa proses pembelajaran jarak jauh dengan menggunakan strategi pembelajaran konvensional atau flipped classroom dan untuk jenis mata kuliah teoritis atau hitungan memberikan beban mental yang cukup besar bagi mahasiswa selaku responden. Beberapa hal yang dapat dilakukan untuk meringankan beban mental mahasiswa jika berdasarkan kuesioner yang dibagikan adalah suasana kelas yang cair, dimana dosen dapat berkomunikasi dengan baik, santai, dan dua arah kepada mahasiswanya, pemberian materi berupa video dengan tampilan menarik dan mudah dipahami juga menarik minat mahasiswa untuk belajar lebih, dan pendampingan saat pemberian tugas juga dirasakan dapat meringankan beban mental mereka.

\section{DAFTAR PUSTAKA}

Febriani, A., Febiyani, A., \& Ma'sum, J. (2021). Calculation of mental load from e-learning student with NASA TLX and SOFI method. Jurnal Sistem Dan Manajemen Industri, 5(1), 35-42. https://doi.org/10.30656/jsmi.v5i1.2789

Harahap, A. C., Harahap, D. P., \& Harahap, S. R. (2020). Analisis Tingkat Stres Akademik Pada Mahasiswa Selama Pembelajaran Jarak Jauh Dimasa Covid-19. Bibliocouns: Jurnal Konseling dan Pendidikan, 1014.

Hartt, S., \& Staveland, L. (1988). Development of NASA Task Load Index (TLX) Result of Empirical and Theoritical Research. California: Nasa-Ames Research.

Human Performance Research Group. (1986). Retrieved from NASA Task Load Index User Manual v. 1.0 (p. 19): https://humansystems.arc.nasa.gov/groups/TLX/downloads/TLX.pdf

Johnson, D., \& Johnson, F. (2013). Joining Together: Group Theory and Group Skills, 11th Ed. Boston, MA: Allyn \& Bacon.

Pandiangan, S., Mahachandra, M., \& Handayani, N. (2019). Analisis Beban Kerja Mental Divisi HR \& GA PT. Pertamina Transkontinental Dengan Metode Rating Scale Mental Effort. Seminar Nasional Teknik Industri Universitas Gadjah Mada, (pp. 42-46).

Prayogo, A. (2016). Evaluasi Beban Kerja Mental Pengatur Perjalanan Kereta Api (PPKA) Dengan Menggunakan Metode Nasa-Tlx Dan Rsme (Studi Kasus Pada PT. KAI DAOP 6 Yogyakarta). Yogyakarta, DI.Yogyakarta, Indonesia: UII.

Rachmuddin, Y., Dewi, D. S., \& Dewi, R. S. (2021). Workload analysis using Modified Full Time Equivalent (M-FTE) and NASA-TLX methods to optimize engineer headcount in the engineering services department. IOP Conference Series: Materials Science and Engineering, 1072(1), 012036. https://doi.org/10.1088/1757-899x/1072/1/012036

Sahimin, Nasution, W. N., \& Sahputra, E. (2017). Pengaruh model pembelajaran dan gaya belajar terhadap hasil belajar PAI siswa kelas VII SMP Negeri 1 Kabanjahe Kabupaten Karo. Edu Riligia, 1(2), 152164. 
Santrock, J. (2008). Psikologi Pendidikan: Edisi Kedua. Jakarta: Kencana.

Sari, W., Rifki, A. M., \& Karmila, M. (2020). Analisis Kebijakan Pendidikan Terkait Implementasi Pembelajaran Jarak Jauh Pada Masa Darurat Covid 19. Jurnal Mappesona.

Susanti, L., \& Hamama Pitra, D. A. (2019). Flipped Classroom Sebagai Strategi Pembelajaran Pada Era Digital. Health \& Medical Journal, 1(2), 54-58. https://doi.org/10.33854/heme.v1i2.242

Widyanti, A., Jonhson, A., \& de Waard, D. (2013). Adaptation of the Rating Scale Mental Efforrt (RSME) for use in Indonesia. International Journal of Industrial Ergonomics 43(1), 70-76.

Zijltra, F. (1993). Efficiency in Work Behaviour: a Design Approach for Modern Tools. Doctoral Thesis. Delft University of Technology. Retrieved from http://repository.tudelft.nl/view/ir/uuid\%3Ad97a028bc3dc- 4930-b2ab-a7877993a17f/.

Ziljstra, F. R., \& Van Doom, L. (1985). Construction of a Scale to Measure Perceived Effort Technical Report. Delft University of Technology. 